\title{
Production and Calculation of Economic Value of the Coffee Skin Waste Products
}

\author{
Sumadi* \\ Management Agribusiness \\ Departement \\ Politeknik Negeri Jember \\ Jember, Indonesia \\ madidhea57@gmail.com
}

\author{
Oryza Ardhiarisca \\ Management Agribusiness \\ Departement \\ Politeknik Negeri Jember \\ Jember, Indonesia \\ oryza_risca@polije.ac.id
}

\author{
Rediyanto Putra \\ Accounting Departement \\ Universitas Negeri Surabaya \\ Surabaya, Indonesia \\ rediyantoputra@unesa.ac.id
}

\begin{abstract}
Sumber Kembang farmer group produced 5,851 $\mathrm{kg}$ of coffee on 4 hectares of land with a waste of $3,510.6 \mathrm{~kg}$. Most of the coffee waste is thrown into the river by farmers so that it can damage the environment and can lead to catastrophic flooding. Even though the coffee skin waste can still be used to improve the economy of coffee farmers. The purpose of this study is to maximize the use of coffee husk waste as a product that has high economic value. This research was conducted at Sumber Kembang Coffee Farmer Group in Durjo Village, Sukorambi District, Jember Regency. This research was conducted by using the method of processing raw materials and calculating the cost of the resulting product to determine the economic value of the product. This research uses a qualitative approach with descriptive methodsThe results of the research that have been done show that coffee husk waste can be used to produce animal feed products and cascara tea by mixing coffee husk waste and other raw materials. In addition, the results of the study also showed that the products produced from processed coffee husk waste have high economic value. This is based on the calculation of costs that have been carried out which shows results that are much lower than the selling price in the market. Based on these results, coffee husk waste should be used optimally to generate additional income for coffee farmers.
\end{abstract}

Keywords - animal feed, cascara tea, coffee skin waste, economic value

\section{INTRODUCTION}

The Sumber Kembang farming group was founded in 2007 in Durjo Village, Sukorambi District, Jember Regency, East Java. The Sumber Kembang coffee farming group produces arabica and robusta coffee with a ratio of $1: 2$ of 1.5 tons (net). This farmer group Arabica coffee has several types, namely full wash, honey and lanang with the name "Casim Coffee". This product is sold in Jember, Banyuwangi, Malang, Belitung, Tanggerang, and Bogor Regencies. Meanwhile, the robusta coffee that is exported is coffee that is still in the form of log coffee by cooperating with PT. Indocom with a turnover of more than 200 million per year.

The opportunity for the development of this farming group has also been proven from the results of activities that have been carried out in 2018 and 2019. The results of the 2018 study show that the Sumber Kembang business group has good business feasibility based on its BC ratio of $2.24 \%$. In addition, based on the results of the 2019 study, it shows that consumers have a satisfaction level of the products produced is $86 \%$. Thus, it can be concluded that the opportunity to develop the Sumber Kembang farmer group business is very large.

Based on the facts found in the field, there are several opportunities for the development of the Sumber Kembang coffee farmer group business that can be produced from the coffee husk waste produced. The Sumber Kembang farmer group produced $5,851 \mathrm{~kg}$ of coffee on 4 hectares of land with a waste of $3,510.6 \mathrm{~kg}$. Most of the coffee waste is thrown into the river by farmers so that it can damage the environment and can lead to catastrophic flooding. Even though the coffee skin waste can still be used to improve the economy of coffee farmers.

Based on these conditions, research related to coffee husk waste becomes a product and the calculation of its economic analysis needs to be done. This is because basically the coffee husk waste can be used as animal feed, fertilizer and cascara tea [1]. This research is in line with the Polije Research Master Plan for the Department of Agribusiness Management, namely Increasing Economic Profits for Agricultural Producers to Take Advantage of Regional Potential Opportunities in One Region to Produce One Local Wisdom Product, Global Class that is Unique to the Region by Utilizing Local Resources (PTUPT scheme) which has technology readiness level (TKT) is five (5) and supports the research priorities of the Jember State Polytechnic in the fields of social humanities, education, arts and culture focus. This research also supports one of the themes in the National Research Master Plan, namely the study of economics and human resources with the topic of entrepreneurship.

The purpose of doing this research in general is to solve problems that exist in the research location, Sumber Kembang Farmer Group. The objectives of this study are (1) Providing solutions in dealing with the problem of coffee husk waste at Sumber Kembang Farmer Group, (2) Determining the economic value of coffee husk waste products that can be produced. The results of this study can provide benefits both academically and practically. The benefits obtained from conducting this research are (1) providing information and / or new sources of reference regarding the benefits of coffee husk waste which can be used as raw material for other products, (2) providing information and / or new sources of reference regarding the economic value of coffee husks. coffee husk waste which is processed into animal feed products, cascara 
tea, compost, and liquid fertilizer, and (3) Providing information and / or reference sources for students, lecturers, and researchers who wish to carry out research with similar research themes.

This research was conducted based on several previous studies with similar themes. In previous research, it has been explained about the use of coffee skin waste, but there is no research that examines the calculation of the cost of this product [2][3]-[6].

\section{METHOD}

The location of this research is located in Durjo Village, Sukorambi District, Jember Regency, East Java Province, Indonesia. This study uses two types of data, namely primary data and secondary data. Primary data in this study is data from interviews with several parties related to the quality of experimental products that have been produced from processed coffee skin waste. The parties who will be used as informants regarding the quality of the experimental products must have knowledge either in practice or theory regarding the standard quality of the product produced from waste coffee husks. Meanwhile, secondary data in this study are financial document data related to experimental products that will be used as the basis for calculating the economic value of the product. Data collection in this study was carried out using several methods. The data collection techniques in this study are as follows.

\section{A. Field Survey.}

This method is the first method used in this study. The goal is to know the condition and important information on the research location to determine the next action that must be taken.

\section{B. Interview.}

The next method is the interview method which is conducted with the aim of obtaining information regarding the assessment of the quality of the coffee skin waste products that have been produced.

\section{Documentation.}

The next method is the documentation method, where this method is used to collect financial data related to coffee skin waste products to determine the economic value it has.

The implementation of this research activity is divided into several stages. These stages are the stages of making coffee skin waste products, evaluating the quality of processed coffee skin waste products, calculating the economic value of processed coffee products, and making research interpretations \& conclusions. The explanation of each of these stages has been briefly explained in the section that discusses the literature review.

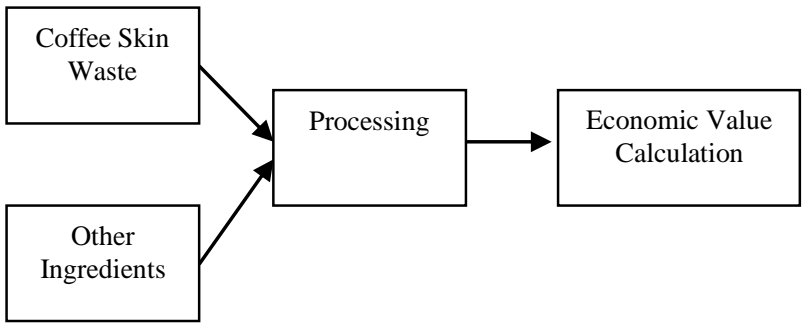

Fig. 1. Research Stages

\section{RESULTS}

\section{A. The Process of Making and Economic Analysis of Animal Feed Products from Coffee Bark Waste}

Animal feed from coffee skin waste provides great benefits for livestock. Giving coffee skin as much as 100-200 gr / head / day to the cow can increase the average growth from $68.15 \mathrm{gr}$ (traditional feed) to $99.25-100.10 \mathrm{gr} / \mathrm{head} /$ day [7].

As animal feed, the coffee waste must be fermented first. This aims to increase its nutritional content. Fermented coffee skins can be used by adding a solution of Aspergillus Niger. The way of making animal feed from coffee husk waste is as follows [8].

The process of making animal feed in this study uses several types of materials, namely coffee bean husk, rice bran, brown sugar, urea, and salt. These ingredients are mixed with a certain percentage to produce a good animal feed product. The percentage of ingredients for making animal feed is as follows:

TABLE I. MATERIALS FOR MAKING ANIMAL FEED

\begin{tabular}{|l|l|c|}
\hline No. & \multicolumn{1}{|c|}{ Raw material } & Percentage \\
\hline 1. & Coffee bean skin husk & $59 \%$ \\
\hline 2. & Rice Bran & $40 \%$ \\
\hline 3. & Brown sugar & $0,25 \%$ \\
\hline 4. & Urea & $0,25 \%$ \\
\hline 5. & Salt & $0,05 \%$ \\
\hline \multicolumn{2}{|c|}{ TOTAL } & $\mathbf{1 0 0 \%}$ \\
\hline
\end{tabular}

The materials that have been prepared are then processed according to a predetermined percentage and the steps that must be taken to produce good animal feed.The steps for making animal feed are as follows:

1. Coffee husk is placed on the tarp and leveled to a height of $20 \mathrm{~cm}$.

2. Next, the coffee skin that has been flattened on the tarp is sprinkled with bran.

3. Dissolve bidecomposer (urea) in water, then add brown sugar and table salt

4. Sprinkle the starbio solution on the coffee skin which has been flattened on a $20 \mathrm{~cm}$ high tarp and has been sprinkled with bran.

5. Stir until all ingredients are well blended.

6. The mixture of coffee skin and starbio solution is put into plastic and covered with a newspaper lined with rubber.

7. Store in a safe place protected from sunlight for 4 days.

8. Air the stored animal feed for 4 days from a protected place for 4 days.

9. Animal feed is ready to be given to livestock. 


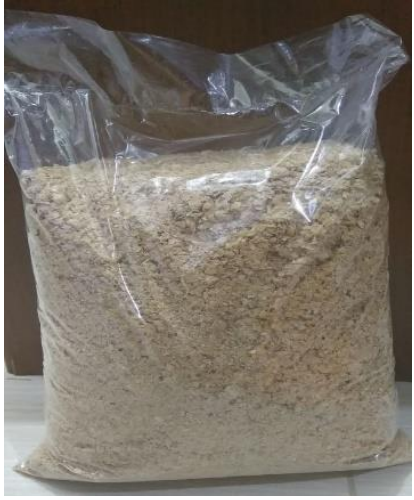

Fig. 2. Coffee Skin Waste Animal Feed Products

All materials used to produce animal feed are then calculated in order to determine the selling value of the finished animal feed product. The process of analyzing the economic value in this study was carried out by calculating the cost value required for each manufacture of coffee skin waste products. Cost analysis is an important information for Sumber Kembang farmer group because this information will be used to determine product price and profit / loss if the product will be sold [9]. The cost calculations performed in this study are variable costs only. This is because this product is an innovative product that has not been sold to the market, so there are no other costs attached to the product. Variable costs determined costs are determined by the level of production volume and controlled by management [10]. The cost calculation for 1 package of $2 \mathrm{~kg}$ compost fertilizer is as follows:

TABLE II. Costs of 2 KG Packaged Animal Feed

\begin{tabular}{|l|l|c|}
\hline No. & Raw Materials & Price \\
\hline 1. & Coffee Bean Husk Husk & $\operatorname{Rp~0,-}$ \\
\hline 2. & Rice Bran & $\operatorname{Rp~} 3.750,-$ \\
\hline 3. & Brown sugar & $\operatorname{Rp~} 83,33$ \\
\hline 4. & Urea & $\operatorname{Rp~} 52,08$ \\
\hline 5. & Salt & $\operatorname{Rp~} 104,17$ \\
\hline 6. & Plastic & $\operatorname{Rp~} 625,-$ \\
\hline 7. & Sticker & $\operatorname{Rp~750,-}$ \\
\hline \multicolumn{2}{|c|}{ TOTAL } & Rp 5.365,- \\
\hline
\end{tabular}

Source: Researcher processed data (2020)

Based on the research results, the production cost for making animal feed so that it is suitable for sale is IDR 5,365 for a $2 \mathrm{~kg}$ package. If a comparison is made with prices in the market, the prices range from IDR 6,000 per kg. This shows that compost products derived from coffee husk waste are competitive in the market.

The animal feed that has been successfully produced in this study, apart from having economic value, also has biological benefits. This is because coffee plant waste has nutritional content, namely protein which increases livestock body weight [11]. The fermentation process of several highfiber wastes including the flesh of the coffee fruit can be useful for improving nutrition [12]. Therefore, the results of this product can be very helpful in the field of agriculture and coffee waste is not wasted.
B. The Process of Making and Economic Analysis of Cascara Tea Products from Coffee Bark Waste

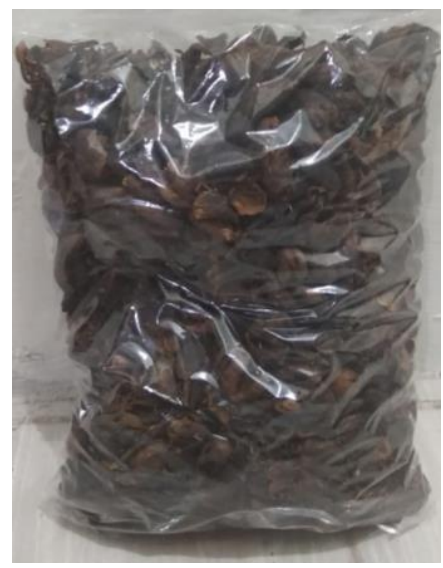

Fig. 3. Coffee Skin Waste Animal Feed Products

The ingredients for making cascara tea are $100 \%$ red arabica coffee beans. The raw material in the form of red bean coffee husk waste is then processed in the following stages:

1. Collect coffee beans that are really bright red and then wash them using a washer machine

2. After that, separate the coffee skins from the coffee beans using a coffee husk separator

3. The coffee bean skin that has been separated from the coffee beans is then dried until it is completely dry for approximately 14-20 days

4. The dried coffee bean skins are ready to be packaged into cascara tea or the coffee bean skins can be ground again if desired in powder form.

5. When finished packing, the cascara tea is ready to be marketed.

From $5 \mathrm{~kg}$ of arabica coffee bean husks, if it is dried on top of a bucket for 7 days, it will become 700 grams of cascara tea. The production costs for 100 gr cascara tea are as follows:

TABLE III. COSTS OF MAKING CASCARA TEA

\begin{tabular}{|c|l|c|}
\hline No. & Raw Materials & Price \\
\hline 1. & Plastic Packaging & Rp 94 \\
\hline 2. & Sticker & Rp 250,- \\
\hline \multicolumn{2}{|c|}{ TOTAL } & Rp 344,- \\
\hline \multicolumn{2}{|r}{} \\
\end{tabular}

Based on the research results, the production cost to make cascara tea worth selling is IDR 344 for a 100 gr package. If a comparison is made with prices in the market, the prices range from IDR 8,000 per 100gr. This shows that compost products derived from coffee husk waste can compete in the market.

The cascara tea product that has been successfully made in this study has economic value and also has health benefits. This is because the proportion of coffee skins used in cascara tea contains $6.11 \%$ crude protein; crude fiber $18.69 \%$; tannins $2.47 \%$; caffeine $1.36 \%$; lignin $52.59 \%$; fat $1.07 \%$; ash $9.45 \%$; calcium $0.23 \%$ and phosphorus $0.02 \%$ [13]. In addition, waste 
from coffee skins also contains several secondary metabilism compounds, namely caffeine and polyphenol groups [14].

\section{CONCLUSION}

This research has produced two products from coffee husk waste, namely animal feed and cascara tea. Based on economic analysis, the two products can compete in the market. This is concluded based on the calculation of the production costs of the two products. The production cost of animal feed is IDR 5,365 for $2 \mathrm{~kg}$ packs. and the production cost of cascara tea is Rp.344, - for a 100 gr package. Based on these data, the by-products produced can compete with prices in the market. This is expected to open farmers' minds that the coffee waste produced has a promising sale value and can help clean the environment.

\section{ACKNOWLEDGMENT}

Gratitude is delivered to all parties who have helped carry out this research well. The first is to the State Polytechnic of Jember who provided support ranging from licensing, administration, and research funding. The next to the Sumber Kembang farmer group, Jember Regency who had given permission to conduct research. The third is tothe respondents who had been willing to fill out the questionnaire that has been given.

\section{REFERENCES}

[1] Warasfarm, "Potensi Urine Sapi Sebagai Pupuk Organik Cair (POC) (Potential of Cow Urine as Liquid Organic Fertilizer (POC)"), 2013. [Online]. Available: https://warasfarm.wordpress.com/2013/01/22/potensi-urine-sapisebagai-pupuk-organik-cair-poc/.

[2] N. N. Palinggi, K. Kamaruddin, and A. Laining, "Perbaikan Mutu Kulit Kopi Melalui Fermentasi Untuk Bahan Pakan Ikan (Improvement of Coffee Skin Quality Through Fermentation For Fish Feed Ingredients)," in Forum Inovasi Teknologi Agrikultur, 2014, pp. 633-637.

[3] H. D. Santoso, S. Surfadi, and S. Syakur, "The Coffee Waste, EM-4 and Mycorrhiza for Improving Soil Quality and Seedling Growth of Arabica Coffee Gayo-1 (Coffea arabica L.)," J. Manaj. Sumberd. Lahan, vol. 3, no. 1, pp. 421-429, 2014.

[4] A. I. Juwita, A. Mustafa, and R. Tamrin, "Studi Pemanfaatan Kulit Kopi Arabika (Coffee Arabica L.) Sebagai Mikro Organisme Lokal (MOL) (Study on the Utilization of Arabica Coffee Skins (Coffee
Arabica L.) as Local Micro Organisms (MOL))," Agrointek, vol. 11, no. 1, pp. 1-8, 2017

[5] E. Novita, A. Fathurrohman, and H. A. Pradana, "Pemanfaatan Kompos Blok Limbah Kulit Kopi Sebagai Media Tanam (Utilization of Coffee Bark Waste Block Compost as Planting Media)," AGROTEK J. Ilm. Ilmu Pertan., vol. 2, no. 2, pp. 61-72, 2019.

[6] B. Supeno, Erwan, and N. M. L. Ernawati, "Diversifikasi Pemanfaatan Limbah Kulit Buah Kopi Untuk Produk Yang Bernilai Ekonomis Tinggi Di Kabupaten Lombok Utara (Diversification of the Utilization of Coffee Fruit Skin Waste for Products of High Economic Value in North Lombok Regency)," in Prosiding PKM-CSR, 2018, vol. 1, pp. 449-457.

[7] S. Guntoro and I. M. . Yasa, "Pemanfaatan Kopi Terfermentasi Untuk Penggemukan Peranakan Ettawah (PE) Muda (Utilization of fermented For Fattening descent Coffee Etawa (PE) Young,)" in Seminar Nasional Revitalisasi Teknologi Kreatif Dalam mendukung Agribisnis dan Otonomi Daerah, 2003, pp. 379-382.

[8] Fakultas Pertanian Universitas Gadjah Mada, "Limbah Kulit Kopi Sebagai Alternatif Pakan Ternak (Coffee Skin Waste as an Alternative for Animal Feed)," 2019. [Online]. Available: https://pakanternak.fapet.ugm.ac.id/2019/01/11/limbah-kulit-kopisebagaialternativepakanternak/.

[9] N. S. Aisyah, "Analisis Nilai Tambah Industri Pengelohan Buah Cherry Kopi (Kasus di Mahkota Java Coffee Garut) Value Added (Analysis of Cherry Coffee Fruit Processing Industry (Case in Mahkota Java Coffee Garut))," Institut Pertanian Bogor, 2018.

[10] Mursyidi, Akuntansi Biaya (Cost Accounting). Bandung: PT. Refika Aditama, 2010

[11] I. M. Londra and P. Sutami, "Pengaruh Pemberian Kulit Kopi Terfermentasi dan Leguminosa untuk Pertumbuhan Kambing Peranakan Etawah (Effect of Fermented Coffee Skin and Leguminous Leaves to Increase the Growth of Etawah Grade Goats)," Inform. Pertan., vol. 22, no. 1, pp. 45-51, 2013.

[12] I. P. Kompiang, "Peningkatan Mutu Bahan Baku Pakan (Quality Improvement of Feed Raw Materials)," in Seminar Pengembangan teknologi Pertanian Ramah Lingkungan, 2000.

[13] M. Sumihati, Widiyanto, and Isroli, "Utilitas Protein Pada Sapi Perah Friesian Holstein Yang Mendapat Ransum Kulit Kopi Sebagai Sumber Serat Yang Diolah Dengan Teknologi Amoniasi Fermentasi (Amofer) (Utilization of Protein in Friesian Holstein Dairy Cows Who Get Coffee Skin Ration as a Source of Fiber Processed with Fermented Ammoniation Technology (Amofer))," Sintesis, vol. 15, no. 1, pp. 1-17, 2011.

[14] D. Nafisah and T. D. Widyaningsih, "Kajian Metode Pengeringan Dan Rasio Penyeduhan Pada Proses Pembuatan Teh Cascara Kopi Arabika (Coffea arabika L.) (The Study of Drying Methods and Brewing Ratios in the Process of Making Arabica Coffee Cascara Tea (Coffea arabica L.))," J. Pangan dan Agroindustri, vol. 6, no. 3, pp. 37-47, 2018 